\title{
CIRI KELAMIN SEKUNDER PADA ARWANA SILVER (Sclerophages macrocephalus) VARIETAS PINOH
}

\author{
Chumaidi*), Agus Priyadi*), Rendy Ginanjar"), dan Linda Sugiarti"*) \\ ") Balai Penelitian dan Pengembangan Budidaya Ikan Hias \\ Jl. Perikanan No. 13, Pancoran Mas, Depok \\ E-mail: publikasi.bppbih@gmail.com \\ *) Lulusan FMIPA, Departemen Biologi, Institut Pertanian Bogor \\ Jl. Meranti, Kampus IPB Darmaga, Bogor 16680
}

(Naskah diterima: 9 Desember 2011; Disetujui publikasi: 8 Mei 2012)

\begin{abstract}
ABSTRAK
Ikan arwana merupakan spesies monomorfik, yaitu hewan yang secara fisik tidak dapat atau tidak mudah dibedakan antara jantan dan betina. Tujuan penelitian ini untuk mengetahui ciri kelamin sekunder yang dapat digunakan sebagai pedoman untuk membedakan jenis kelamin arwana pinoh. Ciri kelamin sekunder yang diamati pada arwana pinoh (Sclerophages macrocephalus) meliputi pengamatan deskriptif dan pengukuran morfometris. Pengamatan diskriptif meliputi bentuk sirip-sirip punggung, ekor, anal, perut, dan dada serta permukaan dagu bawah (mandibula). Sedangkan pengukuran morfometris terdiri atas 29 ukuran morfometris. Pembuktian pendapat di masyarakat mengenai ciri-ciri jantan dan betina arwana juga dianalisis antara lain kerampingan badan (rasio tinggi dan panjang baku), untuk membuktikan jantan lebih ramping dari betina. Besaran kepala (rasio tinggi kepala dan panjang kepala), untuk membuktikan kepala jantan lebih besar dari kepala betina. Kegemukan (rasio panjang baku dan bobon badan), untuk membuktikan bobot badan jantan lebih ringan dibanding betina. Panjang sirip dada (rasio panjang sirip dada dengan panjang baku ikan), untuk membuktikan sirip jantan lebih panjang dibanding betina. Hasil penelitian deskriptif menunjukkan bahwa dari pengamatan bentuk-bentuk sirip tidak terlihat adanya perbedaan antara jenis kelamin jantan dan betina dari arwana pinoh. Diketahui adanya perbedaan permukaan dagu bawah di mana tepi dagu jantan arwana pinoh terasa bergerigi, sedangkan yang betina terasa halus. Pengukuran morfometris yang berkaitan dengan kerampingan, besaran kepala, kegemukan dan panjang sirip ikan arwana juga tidak menunjukkan perbedaan yang nyata atau tidak ada perbedaan antara jantan dan betina.
\end{abstract}

KATA KUNCI: kelamin sekunder, arwana pinoh, morfometrik

ABSTRACT: Secondary sex traits of silver arowana (Sclerophages macrocephalus). By: Chumaidi, Agus Priyadi, Rendy Ginanjar, and Linda Sugiarti

Arowana is a monomorphic species, on the other terms; it is not easy to discriminate sexual differences between male and female physically. The objective of this research was to determined secondary sexual traits as guidelines to trait differently male and female arowana. Descriptive observation and morphometric measurement were used as an instrument to observe and to determine those secondary sexual traits. Fins shape (dorsal, caudal, abdomen, ana and pectorall) and also bottom jaw surface (mandibula) enveloped on those descriptive observation. While for morphometric gauging consists of 29 dimensions. Authentication of society opinion about male and 
female traits different were also analyzed, such as body slenderize (length and height ratio), to show that male arowana are slimmer than the female. Head mulberry (ratio of head length and height), to demonstrate that head of male arowana is bigger than those in female. While to demonstrate that male body weight is bigger than female, fatness (length and body weight ratio) was used as the tools. And length of pectorals fins (ratio of pectorals fins and fish length), was used as a method to demonstrate that male pectoral fin is longer than female pectoral fin. Based on the analysis descriptively (fins shape), result shown that there are no differences between male and female arowana. But we have found some different traits particularly on bottom jaw surface, bottom jaw surface on male arowana is more toothed with cogs, while those in female arowana is more smooth. Quantify of morphometrics (body slenderize, head mulberry, fatness and length of pectorals fins) showed nothing significant differences between male and female arowana.

\section{KEYWORDS: secondary sex, pinoh arowana, morphometric}

\section{PENDAHULUAN}

Pada umumnya arwana merupakan spesies monomorfik (Pouyaud, 2006), yaitu hewan yang secara fisik tidak dapat atau tidak mudah dibedakan antara jantan dan betina terutama pada tingkat muda atau gonadnya belum berkembang. Induk jantan baru dapat dipastikan bila induk sudah dewasa dan dalam pengamatan induk jantan terlihat mengerami telur dalam mulutnya terutama terlihat di malam hari. Sedangkan induk betina terlihat bila perutnya membesar pada waktu gonadnya matang. Pada umur muda hampir semua arwana belum dapat dibedakan kelaminnya. Penelitian determinasi seks arwana banjar dapat melalui teknik penentukan kelamin melalui metode dootblood menggunakan anti vetelogenin (Vtg). Pembuatan antibodi vitelogenin (Vtg) dalam tubuh kelinci dan pengujian antibodi dengan EIA seperti prosedur yang dilakukan oleh Chu-Koo et al. (2008). Vtg didapat dari plasma darah ikan arapaima yang sebelumnya disuntik dengan $17 \beta$-estradiol. Pemurniannya dilakukan melalui elektroforesis yang mendapatkan dua pita yang diketahui sebagai vtg 1 dan vtg2. Penggunaan steroid Vtg dilaporkan pula sebagai teknik yang efisien untuk penentuan jenis kelamin terhadap ikan tuna (Takemura \& Oka, 1998) serta ikan trout dan salmon (Pottinger et al., 2005). Penelitian determinasi seks arwana banjar telah dilakukan melalui metode dootblood (Chumaidi et al., 2009) menggunakan anti vetelogenin (Vtg) dan diupayakan pula menggunakan alat Lateral Flow Device (LFD) untuk mengetahui secara cepat determinasi seks kelamin arwana banjar (Sukarman et al., 2010), namun dalam pelaksanaannya masih banyak kendala dalam penerapannya karena harus menggunakan alat bantu di laboratorium yang cukup canggih dimana pelaksanaannyapun harus cukup terlatih pula. Pembudidaya arwana masih sulit untuk menggunakan peralatan canggih tersebut.

Pengukuran morfometrik sebagai dasar pengklasifikasian ikan telah banyak dilakukan namun tidak terkait dengan pembedaan ciri kelamin ikan (Gustiano \& Pouyaud, 2007; Kusmini et al., 2010; Mulyasari et al., 2009; Nurdawati et al., 2007). Pendapat pembudidaya atau penangkar arwana umumnya mengatakan adanya perbedaan jenis kelamin arwana berdasarkan morfologinya dimana arwana jantan bertubuh lebih ramping, kepala besar, mulut agak lebar, dada dan sirip dada lebih panjang, serta sirip punggung menyempit. Betina bertubuh lebih pendek, lebar, agak gemuk, kepala meruncing dengan mulut lebih kecil. Sirip dada lebih pendek dan sirip punggung melebar pada yang betina (Anonim, 2002). Perbedaan jenis kelamin diketahui pula melalui bentuk tubuh dan lebar mulut. Perbedaan jenis akan muncul setelah ikan berukuran 3-4 tahun. Arwana jantan super red mempunyai tubuh lebih langsing dan sempit, mulut lebih besar, dan warna lebih mencolok daripada betina. Dari pendapat tersebut di atas perlu diperhatikan kaitannya dengan ukuran morfologis ikan arwana seperti kerampingan badan, besaran kepala, panjang sirip, dan lebar dada. Tujuan penelitian ini yaitu untuk mengetahui ciri kelamin sekunder yang dapat digunakan sebagai pedoman untuk membedakan jenis kelamin arwana pinoh.

\section{BAHAN DAN METODE}

Ciri kelamin sekunder yang diamati pada arwana pinoh (Sclerophages macrocephalus) meliputi pengamatan deskriptif dan pengu- 
kuran morfometris. Pengamatan deskriptif meliputi bentuk sirip-sirip punggung, ekor, perut, dada, dan permukaan dagu bawah (mandibula). Sedangkan pengukuran morfometris terdiri atas 29 ukuran morfometris meliputi; 1 . panjang total, 2. panjang baku, 3 . tinggi badan, 4. lebar badan, 5. panjang kepala, 6. tinggi kepala, 7. lebar kepala, 8. panjang bagian kepala belakang mata, 9. Lebar rahang atas, 10 . lebar rahang bawah, 11 . lebar mulut , 12. tinggi pipi, 13. panjang ruang antar mata, 14. panjang antar depan mata, 15 . tinggi di bawah mata, 16. panjang mata-operculum, 17. lebar mata, 18. panjang hidung, 19. panjang dasar sirip dorsal, 20. tinggi sirip dorsal, 21. panjang punggung sirip dorsal, 22. panjang punggung sirip ekor, 23. tinggi sirip ekor, 24. panjang dasar sirip anal, 25. tinggi sirip anal, 26. panjang sirip perut, 27 . tinggi sirip perut, 28. panjang sirip dada, 29. tinggi sirip dada (Gambar 1).

Pembedahan ikan dilakukan setelah pengukuran morfometris untuk mengidentifikasi jenis kelamin ikan arwana sebenarnya berdasarkan jenis gonadnya. Selanjutnya hasil ukuran morfometris dikelompokkan berdasar jenis kelaminnya, di mana didapat dua ekor jantan dan lima ekor betina.

Pembuktian pendapat di masyarakat mengenai ciri-ciri jantan dan betina arwana juga dianalisis antara lain kerampingan badan (rasio tinggi dan panjang tubuh), untuk membuktikan jantan lebih ramping dari betina. Besaran kepala (rasio tinggi kepala dan panjang kepala), untuk membuktikan kepala jantan lebih besar dari kepala betina. Kegemukan (rasio panjang baku dan bobot badan), untuk membuktikan bobot badan jantan lebih ringan dibanding betina. Panjang sirip dada (rasio panjang sirip dada dengan panjang baku ikan), untuk membuktikan sirip jantan lebih panjang dibanding betina.

Analisis data ukuran morfometri berbagai jenis sirip serta perbedaan alometrik terkait dengan kerampingan, besaran kepala, kegemukan dan rasio pajang sirip dada dari ikan arwana jantan dan betina menggunakan program SPSS 16.

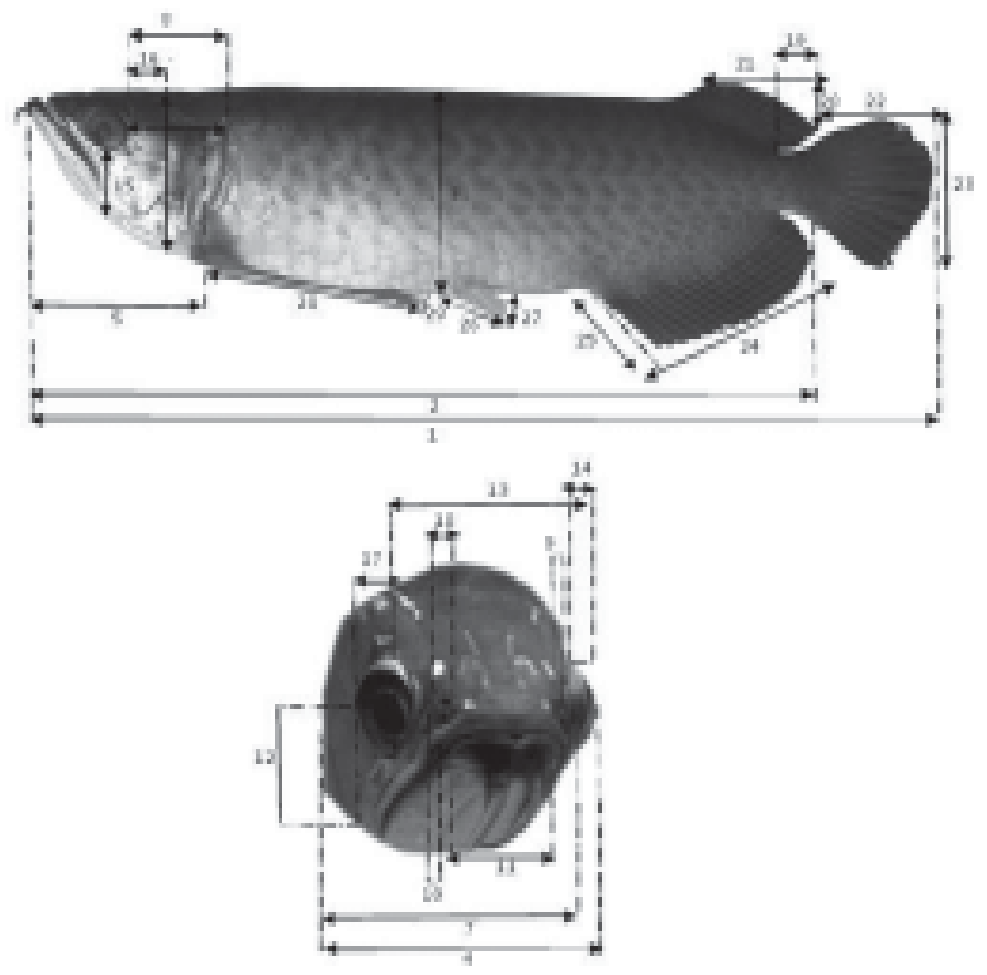

Gambar 1. Pengukuran morfometri ikan arwana pinoh

Figure 1. Morphometric measurements of pino arowana 


\section{HASIL DAN BAHASAN}

Hasil dari pengamatan kelamin sekunder arwana pinoh secara diskriptif terutama sirip punggung memiliki dua bentuk yaitu membulat dan meruncing. Sirip yang membulat terlihat dari pinggiran sirip membentuk lengkungan sedangkan sirip yang meruncing, pinggiran sirip berbentuk tajam. Perbandingan antara jantan dan betina menunjukkan bahwa bagian ujung dorsal bagian belakang (dorso posterior) tidak berbeda, baik jenis jantan (Gambar 2A, 2B) maupun betina (Gambar 2C, 2D, 2E, 2F, 2G.), ada yang meruncing namun ada pula yang membulat. Sirip pungung pada ikan-ikan jantan blue acara (Aequidens pulcher) dan betok (Anabas testudineus (B)) panjang dan runcing (Lingga \& Susanto, 1989; Berra, 2001; Axelrods et al., 2004). Bentuk sirip ekor menunjukkan bentuk yang membulat dengan pinggiran sirip yang melengkung dari ujung dorsal hingga bagian ventral. Bentuk sirip ekor antara jantan (Gambar 3A, 3B.) dan betina (Gambar 3C, 3D, 3E, 3F, 3G) juga tidak ada perbedaan di mana hampir semuanya ujungnya membulat. Selanjutnya sirip anal ujung ventral bagian belakang (ventro posterior) memiliki bentuk yang deragam dengan bentuk membulat panjang dari perut menuju anal. Perbedaan sirip anal antara jantan (Gambar 4A, 4B.) dan betina (Gambar 4C, 4D, 4E, 4F, 4G) juga tidak menunjukkan perbedaan di mana ujung ventro posterior membentuk siku yang tumpul. Sirip anal pada ikan betina rata-rata tidak berkembang pada ikan Nomorhaphus towoeti (Anonim, 2006) Bentuk lubang anal baik jantan maupun betina tidak terlihat pula perbedaan, di mana bentuknya membulat. Organ reproduksi jantan berbentuk oval dan betina berbentuk bulat serta menonjol pada ikan mas

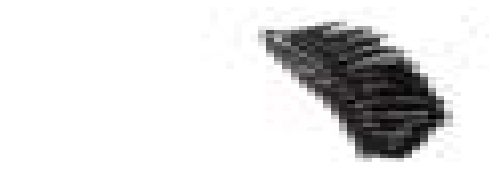

A

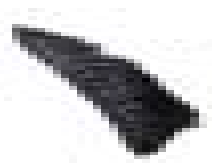

C

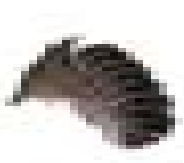

D

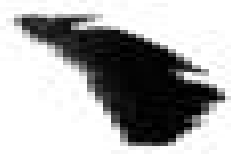

B

Jantan (Male)

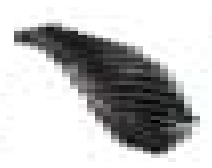

$\mathrm{E}$

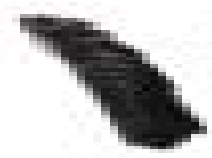

F

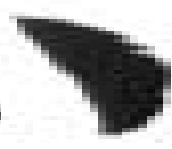

G

Betina (Female)

Gambar 2. Sirip punggung arwana pinoh

Figure 2. Dorsal fin of pino arowana

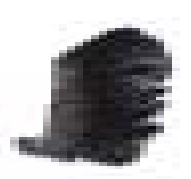

A

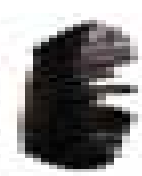

B Jantan (Male)

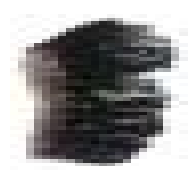

C

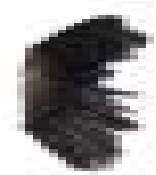

D

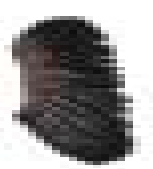

$\mathrm{E}$

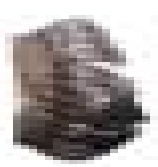

F

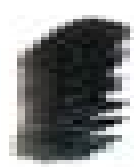

G

Betina (Female)

Gambar 3. Sirip ekor arwana pinoh

Figure 3. Caudal fin of pino arowana 


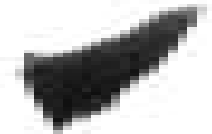

A

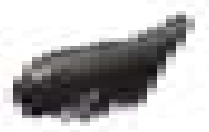

B

Jantan (Male)

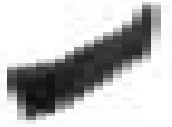

C

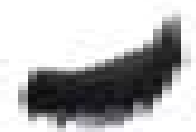

D

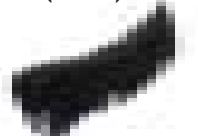

$\mathrm{E}$

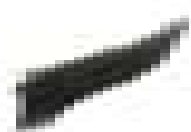

$\mathrm{F}$

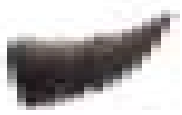

G

Betina (Female)

Gambar 4. Sirip anal arwana pinoh

Figure 4. Annal fin of pino arowana

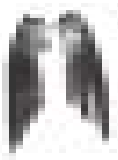

A

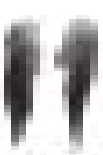

D

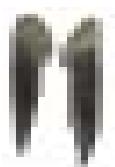

B

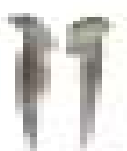

$\mathrm{F}$

Betina (Female)

Gambar 5. Sirip perut arwana pinoh

Figure 5. Abdomen fin of pino arowana

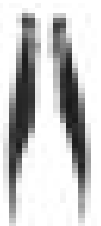

A

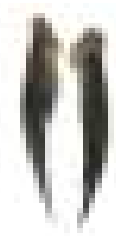

B Jantan (Male)

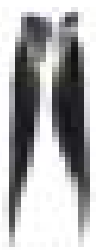

C

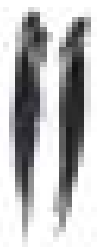

D

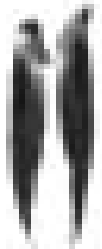

$\mathrm{E}$

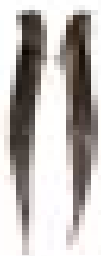

$\mathrm{F}$
G

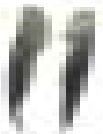

Betina (Female)

Gambar 6. Sirip dada arwana pinoh

Figure 6. Pectoral fin of pino arowana 


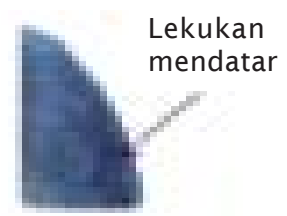

A

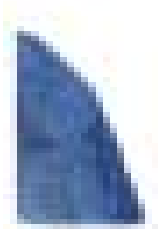

C

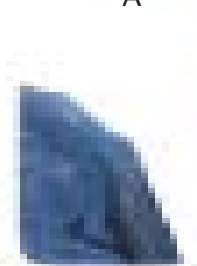

D

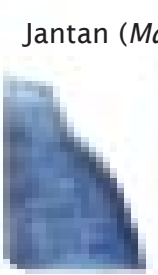

$\mathrm{E}$

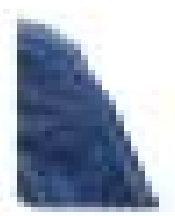

B

Lekukan ke bawah

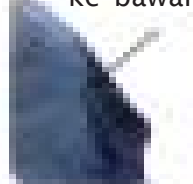

$\mathrm{F}$

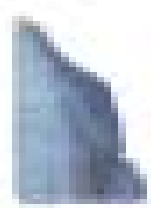

G

Betina (Female)

Gambar 7. Morfologi dagu bawah arwana pinoh

Figure 7. Morphological of bottom jaw surface pino arowana

koki (Perkasa \& Hisomudin, 2002) dan ikan baung (Anonim, 2003). Demikian pula bentuk sirip perut jantan (Gambar 5A, 5B) dan betina (Gambar 5C, 5D, 5E, 5F, 5G) serta sirip dada jantan (Gambar 6A, 6B) dan betina (Gambar 6C, 6D, 6E, 6F, 6G) bentuknya sama-sama meruncing pada ujungnya.

Perbedaan yang mencolok antara jantan dan betina arwana pinoh yaitu pada dagu bawah sebelah tepi (ventro lateral) di mana bila diraba, dagu tepi dari jantan terasa bergerigi, sedangkan yang betina terasa halus. Foto dagu bawah sebelah lateral (dengan perbesaran gambar) pada yang jantan terlihat adanya lekukan yang melintang (transfersal) (Gambar 7A, 7B.) sedangkan yang betina hanya terlihat lekuan yang memanjang (longitutidial) (Gambar 7C, 7D, 7E, 7F, 7G).

Pengukuran morfometrik dari morfologi arwana baik jantan dan betina bahwa dari 29 ukuran morfometrik dari tinggi badan ikan hingga tinggi sirip anal terlihat bervariasi dan tidak menunjukkan perbedaan khas yang membedakan jenis kelamin arwana jantan dan betina (Tabel 1 ).

Pembuktian pendapat di masyarakat mengenai ciri-ciri jantan dan betina arwana di antaranya kerampingan badan. Ikan arwana bila dilihat dari samping (dorso ventral), tinggi badan terlihat lebih pendek akan dinyatakan lebih ramping dibanding ikan dengan tinggi badan lebih tinggi. Kerampingan badan lebih jelas bila dibandingkan antara tinggi badan dan panjang badan. Setelah dianalisis secara statistik antara lain kerampingan badan (perbedaan rasio tinggi dan panjang badan) (Tabel 2), ikan jantan dan betina arwana pinoh tidak menunjukkan perbedaan nyata $(P>0,05)$. Bentuk tubuh ikan balashark berkelamin jantan lebih ramping dibanding betina (Sudarto \& Yuliati dalam Chumaidi et al., 2007). Ikan papuyu jantan juga ramping dan panjang, sedangkan betina gemuk lebar (Anonim, 2003). Sedangkan ikan-ikan hias lainya seperti bentuk tubuh ikan-ikan Arulius dan Oskar lebih panjang dibanding betina (Lingga \& Susanto, 1989).

Kepala ikan arwana pinoh jantan dianggap oleh masyarakat lebih besar dari yang betina, di mana mulut ikan arwana jantan untuk mengerami telur. Pada arwana super red, masyarakat menganggap besaran kepala arwana jantan lebih besar dibanding arwana betinanya (Anonim, 2002). Hasil analisis statistik besaran kepala (perbedaan rasio tinggi kepala dan panjang kepala) pada Tabel 2. Ikan jantan dan betina arwana pinoh tidak menunjukkan perbedaan nyata pula ( $P>0,05)$.

Kegemukan ikan arwana bisa dianggap dari perbandingan panjang baku dan bobot ikan. Pada arwana super red, masyarakat menganggap bobot badan arwana betina lebih berat dibanding arwana jantan (Anonim, 2002). Kegemukan badan (perbedaan rasio panjang baku dan bobot badan) pada Tabel 2, ikan jantan dan betina arwana pinoh semuanya tidak menunjukkan perbedaan nyata $(P>0,05)$. 
Tabel 1. Pengukuran morfometris dari arwana pinoh

Table 1. Morphometric measurement of pino arowana

\begin{tabular}{|c|c|c|c|c|c|c|c|}
\hline \multirow{2}{*}{$\begin{array}{c}\text { Ukuran morfometrik } \\
\text { Morphomet ric measurement }\end{array}$} & \multicolumn{2}{|c|}{$\begin{array}{c}\text { Jant an (Male) } \\
\qquad(\mathrm{cm})\end{array}$} & \multicolumn{5}{|c|}{$\begin{array}{l}\text { Bet ina (Female) } \\
(\mathrm{cm})\end{array}$} \\
\hline & $\mathrm{J} 1$ & $\mathrm{~J} 2$ & B 1 & B3 & B4 & B4 & B5 \\
\hline Panjang total (Total length) & 40 & 39.8 & 41.5 & 37.5 & 41 & 39 & 34 \\
\hline Panjang baku (Standart length) & 31 & 31 & 33.6 & 33 & 36.5 & 30.5 & 30.5 \\
\hline Tinggi badan (Body height) & 9 & 8.63 & 10.43 & 8 & 9.2 & 8.15 & 7.4 \\
\hline Lebar badan (Body weight) & 4.2 & 5.02 & 5.05 & 4.05 & 4.2 & 4.4 & 4.1 \\
\hline Panjang kepala (Head length) & 9.4 & 9 & 9 & 8 & 9.7 & 8.1 & 8 \\
\hline Tinggi ke pala (Head height) & 4.03 & 7.5 & 4.3 & 6.3 & 7.9 & 7 & 6.3 \\
\hline Lebar kepala (Head weight) & 7.4 & 4.2 & 7.26 & 3.6 & 4.3 & 3.9 & 3.5 \\
\hline $\begin{array}{l}\text { Panjang kepala belakang mata } \\
\text { Head length-Eye caudal }\end{array}$ & 4.5 & 5.4 & 4.5 & 3.8 & 6 & 4.1 & 5 \\
\hline Lebar rahang atas (Upper jaw weight) & 0.4 & 0.5 & 0.6 & 0.5 & 0.5 & 0.5 & 0.2 \\
\hline $\begin{array}{l}\text { Lebar rahang bawah } \\
\text { Lower jaw weight }\end{array}$ & 0.7 & 0.6 & 0.7 & 0.7 & 0.6 & 0.7 & 0.5 \\
\hline Lebar mulut (Mouth weight) & 2.2 & 6.3 & 2 & 1.1 & 1.5 & 6.2 & 5.6 \\
\hline Tinggi pipi (Chin height) & 2.7 & 2.6 & 3 & 2.7 & 5.2 & 2.6 & 2.2 \\
\hline $\begin{array}{l}\text { Panjang antar ruang mata } \\
\text { Inter eye length }\end{array}$ & 3.13 & 2.7 & 3.2 & 3 & 3.3 & 2.8 & 2.5 \\
\hline $\begin{array}{l}\text { Panjang antar de pan mata } \\
\text { Inter center cornea length }\end{array}$ & 0.9 & 0.8 & 1 & 1.5 & 1.5 & 0.7 & 0.7 \\
\hline $\begin{array}{l}\text { Tinggi di bawah mata } \\
\text { Lower eye height }\end{array}$ & 1.8 & 0.9 & 1.2 & 1.1 & 0.9 & 0.7 & 0.8 \\
\hline $\begin{array}{l}\text { Panjang mata-operculum } \\
\text { Eye length-operculum }\end{array}$ & 5 & 5.6 & 4.7 & 4.1 & 6 & 4.2 & 5.1 \\
\hline Lebar mata (Eye weight) & 1.6 & 1.8 & 1.9 & 1.7 & 1.6 & 1.8 & 1.8 \\
\hline Panjang hidung (Nouse length) & 0.5 & 0.9 & 1.3 & 1 & 1 & 1.1 & 1 \\
\hline $\begin{array}{l}\text { Panjang dasar sirip dorsal } \\
\text { Lower dorsal fin length }\end{array}$ & 4 & 4.5 & 7.3 & 4.5 & 5.3 & 4.5 & 6.5 \\
\hline Tinggi sirip dorsal (Dorsal fin height) & 5.4 & 2 & 4.4 & 2.5 & 2.5 & 3 & 3.5 \\
\hline $\begin{array}{l}\text { Panjang punggung sirip dorsal } \\
\text { Dorsal fin length }\end{array}$ & 27 & 27.4 & 29.1 & 25.5 & 29 & 27.4 & 20.6 \\
\hline Panjang sirip ekor (Caudal fin length) & 4 & 4.07 & 8 & 3.9 & 3.9 & 4.4 & 3.9 \\
\hline Tinggi sirip ekor (Caudal fin height) & 2.85 & 2.5 & 2.7 & 2.16 & 2.5 & 2.75 & 2.2 \\
\hline Panjang sirip anal (Annal fin length) & 23 & 7.1 & 11.5 & 6.5 & 8 & 7.5 & 7 \\
\hline Tinggi sirip anal (Annal fin height) & 5 & 2.2 & 5.5 & 2.5 & 2.5 & 3 & 1.8 \\
\hline $\begin{array}{l}\text { Panjang sirip perut } \\
\text { Abdomen fin length }\end{array}$ & 5 & 1.49 & 4.1 & 4.7 & 4.9 & 4.9 & 5.1 \\
\hline $\begin{array}{l}\text { Tinggi sirip perut } \\
\text { Abdomen fin height }\end{array}$ & 1.0 & 1.2 & 0.7 & 0.9 & 1.9 & 0.9 & 0.7 \\
\hline $\begin{array}{l}\text { Panjang sirip dada } \\
\text { Pectoral fin length }\end{array}$ & 10.2 & 9.2 & 9.7 & 10.6 & 10 & 11.2 & 8.8 \\
\hline Tinggi sirip dada (Pectoral fin height) & 5 & 4.9 & 4.1 & 4.7 & 4.9 & 4.9 & 5.1 \\
\hline
\end{tabular}


Tabel 2. Perbandingan kerampingan, besaran kepala, kegemukan badan dan panjang sirip dada Table 2. Ratio of morphometrics (body slenderize, head mulberry, fatness and length of pectorals fins)

\begin{tabular}{|c|c|c|c|c|c|c|c|}
\hline \multirow{2}{*}{$\begin{array}{l}\text { Perbandingan morfometri } \\
\text { Morphometric ratio }\end{array}$} & \multicolumn{2}{|c|}{ Jant an (Male) } & \multicolumn{5}{|c|}{ Betina (Female) } \\
\hline & Al & A2 1 & A2 & A3 & A4 & A20 & A25 \\
\hline $\begin{array}{l}\text { Ke rampingan badan } \\
\text { Body slenderize }\end{array}$ & 0.2903 & 0.2783 & 0.3104 & 0.2424 & 0.2520 & 0.2672 & 0.2426 \\
\hline $\begin{array}{l}\text { Besaran ke pala } \\
\text { Head mulberry }\end{array}$ & 0.4287 & 0.8333 & 0.4777 & 0.7875 & 0.8144 & 0.8641 & 0.7875 \\
\hline $\begin{array}{l}\text { Kegemukan badan } \\
\text { Body mulberry }\end{array}$ & 0.0426 & 0.0485 & 0.0413 & 0.0687 & 0.0528 & 0.0543 & 0.0756 \\
\hline $\begin{array}{l}\text { Panjang sirip dada } \\
\text { Length of pectorals fins }\end{array}$ & 0.1354 & 0.1619 & 0.1502 & 0.1227 & 0.1150 & 0.1442 & 0.1344 \\
\hline
\end{tabular}

Sirip dada dikatakan relatif panjang bila dilihat dari samping (dorso ventral) bila dibandingkan dengan panjang baku ikan. Sirip dada lebih pendek pada ikan betina arwana super red (Anonim, 2002). Hasil analisis statistik panjang sirip dada (perbedaan rasio panjang sirip dada dengan panjang baku ikan) (Tabel 2) ikan jantan dan betina arwana pinoh tidak menunjukkan perbedaan nyata pula $(P>0,05)$.

\section{KESIMPULAN}

Hasil penelitian deskriptif menunjukkan bahwa dari pengamatan bentuk-bentuk sirip tidak terlihat adanya perbedaan antara jenis kelamin jantan dan betina dari arwana pinoh. Diketahui adanya perbedaan permukaan dagu bawah di mana tepi dagu jantan arwana pinoh terasa bergerigi, sedangkan yang betina terasa halus. Pengukuran morfometris yang berkaitan dengan kerampingan, besaran kepala, kegemukan, dan panjang sirip ikan arwana juga tidak menunjukkan perbedaan yang nyata atau tidak ada perbedaan antara jantan dan betina.

\section{DAFTAR ACUAN}

Anonim. 2002. Panduan praktis tangkaran arwana kualitas ekspor. Trubus, 2002, 16 hlm.

Anonim. 2003. Pembenihan ikan spesifik lokal baung dan papuyu. Departemen Kelautan Perikanan. Direktorat Jenderal Perikanan Budidaya. Loka Budidaya Air Tawar Mandiangin, Kalimantan Selatan, $23 \mathrm{hlm}$.
Anonim. 2006. Ikan Air Tawar Langka di Indonesia. Direktorat Konservasi dan Taman Nasional Laut. Dirjen Kelautan, Pesisir dan Pulau-Pulau Kecil. Departemen Kelautan dan Perikanan, $53 \mathrm{hlm}$.

Axelrod, H.R., Axelrod, G.S., Burgerss, W.E., Scott, B.M., Pronek, N., \& Wall, J.G. 2004. Dr Axelrod's Atlas of Freshwater Aquarium Fishes, 10 edition TPH Publications One TPF Place, Third and Union Avenues. Neptune City. NJ 07753, p. 11-58.

Berra, T.M. 2001. Freswater Fish Distribution. Academic Press. Harwurt Place, 32 Jamestown Road, London NW1 7BY, UK, $604 \mathrm{pp}$.

Chu-Koo, R., Dugue, M.A., Aguliar, Daza, A.C., Bocanega, F.A., Veintamilla, C.C., Duponchelle, F., Renno, J.F., Tello, S., \& Nunez, J. 2008. Gender determination in the Paiche or Pirarucu (Arapaima gigas) using plasma vitellogenin, $17 \beta$-estradiol and 11-ketotestoterone levels. Fish Physiol Biochem D01 10 -1007/s 10695-9211-8.

Chumaidi, Priyadi, A., \& Musa, A. 2009. Determinasi seks arwana silver (Scleropages). Laporan Teknis Penelitian Balai Riset Budidaya Ikan Hias, Depok, Tahun 2009, $8 \mathrm{hlm}$.

Gustiano, R. \& Pouyaud, L. 2007. Taxonomy and genetic relationships of Pangasidae, Asian catfishes based a morphological and moleculer analysies. Ind. Aqua. Journal, 2(2): 75-162.

Kusmini, I.I., Gustiano, R., \& Mulyasari. 2010. Karakteristik transmorfometrik ikan trans- 
genik (Barbonymus schanenfldii) asal Kalimantan Barat dengan ikan tengadak dan ikan tawes asal Jawa Barat. Forum Inovasi Teknologi Akuakultur, Buku 1, Pusat Penelitian dan Pengembangan Perikanan Budidaya, hlm. 507-513.

Lingga, P. \& Susanto, H. 1989. Ikan Hias Air Tawar. Seri Perikanan XXIV/255/87. Penebar Swadaya, $236 \mathrm{hlm}$.

Mulyasari, Kusmini, I.I., \& Huwyon, G.H. 2009. Karakter morfologi ikan nilem hijau (Osteocheilus hasselti) asal Jawa Barat dan ikan kalabau (Osteocheilus sp.) asal Jawa Barat dan ikan kalabau (Osteocheilus sp.) asal Kalimantan Barat. Forum Inovasi Teknologi Akuakultur, Buku 2, Pusat Penelitian dan Pengembangan Perikanan Budidaya, hlm. 659-663.

Nurdawati, S., Oktaviani, D., Makmur, S., Wargasasmita, S., Rahmatika, I., \& Haryono. 2007. Tata Nama Spesies Ikan Air Tawar Indonesia. Ditinjau dari perkembangan taksonomi. Pusat Riset Perikanan Tangkap. Badan Riset Kelautan dan Perikanan, $97 \mathrm{hlm}$. Forum Inovasi Teknologi Akuakultur, Buku 1, Pusat Penelitian dan Pengembangan Perikanan Budidaya.

Perkasa, B.E. \& Hisomudin. 2002. Permasalahan mas koki solusinya. Seri Agrisolusi. Penebar Swadaya, $101 \mathrm{hlm}$.
Pottinger, T.G., Pulman, K.G.T., Carrick, T.R., \& Scout, A.P. 2005. Evaluation of biochemical methods for the non-distructive identification of sex in upstream migrating salmon abd sea trout. J. Fish. Biol., 67: 1514-1533.

Pouyaud, L. 2006. Management of arwana in re-circulated water system a new challenge. Seminar Ikan Hias Nusantara, 2006, $85 \mathrm{pp}$.

Subandiyah, S., Sudarto, \& Satyani, D. 2008. Determinasi ukuran ikan dengan parameter gonad ikan hias tilan merah. Seminar Teknologi Perikanan Budidaya. Pusat Riset Perikanan Budidaya, p. 57-62.

Sudarto \& Yulian, P. 2007. Pengenalan ikan Balashark (Balantiocheilus melanopterus) dalam Chumaidi, D. Satyani, dan Sudarto. Teknik Pembenihan Ikan Balashark (Balantiocheilus melanopterus). Loka Riset Budidaya Ikan Hias Air Tawar, hlm. 5-10.

Sukarman, Chumaidi, Wibawa, G.S., Gardenia, L., Musa, A., \& Priyadi, A.. 2010 . Rekayasa alat uji kelamin secara cepat untuk ikan arwana (Scleropages macrocephalus) varietas Banjar. Laporan Teknis Penelitian Balai Riset Budidaya Ikan Hias, Depok, Tahun 2010, 12 hlm.

Takemura, A. \& Oka, M. 1998. Immunochemical sexing of living yellowfin tuna, Thunnus albacares (Bonnaterre), using a vitellogeninlike protein. Aqua. Res., 29: 245-249. 